\title{
PENGARUH PEMBELAJARAN VARIASI DAN FASILITAS TERHADAP PRESTASI MAHASISWA PADA MATERI AKUNTANSI PENGANTAR DENGAN MOTIVASI SEBAGAI VARIABEL MODERATING
}

\author{
Emi Kusmaeni \\ Sekolah Tinggi Ilmu Ekonomi Surabaya \\ emikusmaeni@stiesia.ac.id \\ Endah Sulistyowati \\ Sekolah Tinggi Ilmu Ekonomi Surabaya \\ endahsulis60@ymail.com
}

Received: 07-03-17

Reviewed: $14-03-17$

Accepted: 25-04-17

Published: 20-07-17
ABSTRAK

Pendidikan merupakan bagian yang terpenting didalam program pembangunan saat ini karena mempengaruhi dalam pengembangan sumber daya manusia yang kompeten dan berkualitas. Hal tersebut diharapkan agar sumber daya manusia yang dimiliki akan berdampak pada keberhasilan suatu pembangunan di berbagai sektor. Namun dalam kondisi nyata, beberapa lulusan tidak kompeten dan tidak berkualitas dibidangnya. Untuk itu, dengan penelitian ini diharapkan dapat mengidentifikasi faktor yang mempengaruhi prestasi antara lain metode pembelajaran variasi, fasilitas belajar, dan motivasi sebagai variabel moderating. Metode penelitian yang digunakan untuk mengumpulkan respoden yaitu dengan membagikan kuesioner dengan pengujian yang dilakukan untuk melihat hubungan dari ketiga variabel digunakan uji interaksi Moderated Regression Analysis. Hasil penelitian menunjukkan bahwa variabel yang digunakan mempengaruhi prestasi dan diperkuat dengan adanya motivasi belajar dari setiap individu. Namun hasil yang disajikan hanya memiliki pengaruh yang rendah, artinya bahwa masih terdapat variabel lain yang mempengaruhi prestasi dan tidak digunakan dalam penelitian ini.

Kata Kunci: Akuntansi Pengantar, Fasilitas, Motivasi, Pembelajaran Variasi, dan Prestasi Belajar.

\section{PENDAHULUAN}

Pendidikan adalah bagian yang tidak terpisahkan dari keberhasilan dari program pembangunan karena itu pendidikan harus diarahkan dalam pengembangan sumber daya manusia yang berkualitas dan kompeten dan diharapkan akan berdampak pada keberhasilan pembangunan di berbagai sektor. Sedangkan berkualitasnya sumber daya manusia dapat dilihat dari segi pendidikan yang telah terkandung secara jelas dalam tujuan pendidikan nasional (Hamalik, 2013:1). Pendidikan dilaksanakan dalam upaya untuk mempersiapkan peserta didik dalam kegiatan yang berkaitan dengan pengajaran yang telah disusun secara terstruktur sesuai dengan kurikulum yang berlaku secara meyeluruh. Untuk dapat menilai keberhasilan suatu pendidikan dapat dilihat dengan prestasi belajar 
mahasiswa. Menurut Muhibbin dalam

Adiningsih (2012) "Prestasi belajar adalah tingkat keberhasilan siswa dalam mencapai tujuan yang ditetapkan dalam sebuah program". Prestasi belajar merupakan pengukuran dan penilaian atau merupakan suatu alat evaluasi hasil prestasi belajar mahasiswa karena telah melakukan proses pembelajaran yang mana untuk mengetahui suatu prestasi dilakukan tes dan hasilnya disimbolkan dalam bentuk angka, huruf maupun kalimat yang menceritakan hasil yang telah dicapai. Dengan penilaian tersebut, akan dapat diketahui tingkat pemahaman peserta didik atau mahasiswa. Untuk mencapai prestasi belajar yang optimal, tidak hanya dipengaruhi oleh metode pengajaran yang dilakukan oleh pendidik. Namun juga dapat dipengaruhi oleh faktor internal dan eksternal menurut Dalyono dalam Adiningsih (2013). Kedua faktor tersebut memiliki keterkaitan yang besar dalam menghasilkan prestasi belajar yang optimal. Salah satu faktor internal yang sangat berpengaruh adalah faktor minat dan motivasi. Dalyono dalam Adiningsih (2012) menyebutkan minat belajar yang besar cenderung menghasilkan prestasi yang tinggi, sebaliknya minat belajar yang kurang akan menghasilkan prestasi yang rendah. Dan kuat lemahnya motivasi belajar seseorang turut mempengaruhi keberhasilannya.

Para pendidik haruslah memiliki teknik pembelajaran yang dapat mendukung untuk menghasilkan lulusan berkompeten. Mereka memiliki lebih dari satu teknik pembelajaran agar dapat dipahami oleh para peserta didik dan disesuaikan dengan situasi kelas masing-masing atau sesuai dengan tingkat pemahaman peserta didik yang di didik pada waktu tersebut. Bates dan Woldrup (2006) telah melakukan penelitian tentang teknik pembelajaran yang dapat mendukung tingkat pemahaman dan sikap prinsip akuntansi dasar dengan untuk menentukan apakah suatu metode pembelajaran tertentu mengakibatkan dampak kinerja yang terukur antara dasar-dasar akuntansi dan dalam sikap siswa terhadap profesi akuntansi sesuai dengan yang disampaikan oleh pendidik mereka. Hasil dari penelitian tersebut menyajikan bahwa tidak ada perbedaan yang signifikan antara kinerja siswa atau sikap siswa pada penggunaan powerpoint dan metode tradisional. Namun dalam menentukan metode pembelajaran, pendidik harus memperhatikan karakteristik atau gaya belajar mahasiswa sehingga antara penyampaian dan penerimaan akan sesuai dengan tujuan materi yang disampaikan.

Penelitian yang dilakukan oleh Adiningsih (2012) membahas tentang pengaruh persepsi siswa tentang metode mengajar guru dan kemandirian belajar terhadap prestasi belajar akuntansi siswa kelas $\mathrm{X}$ program keahlian akuntansi SMK Batik Perbaik Purworejo Tahun Ajaran 2011/2012. Dalam penelitian tersebut, Adiningsih dapat melihat faktor lain yang mempengaruhi prestasi belajar adalah faktor kemandirian belajar. Beberapa siswa malas 
dalam belajar akuntansi dan hanya akan belajar ketika akan ada ujian. Hal tersebut mengindikasikan bahwa kemandirian belajar siswa masih rendah. Umar Tirtarahardja dan S.L. La Sulo dalam Adiningsih (2012) menyatakan bahwa "Kemandirian dalam belajar adalah aktivitas belajar yang berlangsungnya lebih didorong oleh kemauan sendiri, pilihan sendiri dan tanggung jawab sendiri”. Dengan kemandirian belajar, siswa akan belajar menguasai materi dengan usaha sendiri tanpa adanya guru atau disuruh orang tua sehingga siswa akan cenderung positif untuk mencapai tujuan dengan menguasai materi dan memperoleh prestasi yang memuaskan. Dalam penelitian tersebut diketahui bahwa metode yang digunakan guru dalam mengajar masih monoton yaitu hanya metode ceramah, tanya jawab, dan metode pemberian tugas.

Hasil penelitian yang telah diuraikan tersebut dapat dilihat bahwa prestasi belajar dipengaruhi oleh beberapa faktor internal dan eksternal diantaranya metode pengajaran pendidik, penggunaan alat atau media dalam penyampaian materi, serta minat dan motivasi dari peserta didik. Metode yang digunakan pendidik hanya dengan model ceramah tidak akan memberikan hasil yang maksimal. Model ceramah, tanya jawab dan pemberian tugas juga tidak akan menghasilkan prestasi yang cukup. Apabila metode tersebut diimbangi dengan penggunaan media pembelajaran yang cukup memadai akan lebih efektif. Metode pengajaran kooperatif juga memberikan hasil yang lebih efektif daripada metode pengajaran masalah. Sehingga dapat disimpulkan dalam melaksanakan proses pembelajaran untuk penentuan metode pengajaran pendidik harus kreatif dalam menentukan metodenya. Selain kreatifitas, pendidik juga harus memperhatikan motivasi dari peserta didik agar prestasi belajar yang dihasilkan benar-benar maksimal. Motivasi belajar sangat berpengaruh terhadap prestasi belajar. Hal ini seperti penelitian yang dilakukan oleh Aminah dalam Adiningsih (2012) yang menyebutkan bahwa terdapat pengaruh positif dan signifikan motivasi belajar terhadap prestasi belajar akuntansi.

Apabila pendidik hanya menyajikan metode pengajaran yang sama secara terus menerus akan menimbulkan kebosanan pada peserta didik bahkan pendidik pun kemungkinan juga mengalami kebosanan tersebut. Sehingga disini pendidik harus menggunakan variasi untuk mengurangi tingkat kebosanan yang dihadapi oleh peserta didik. Apabila siswa atau peserta didik mengalami kebosanan hal tersebut memungkinkan perhatian siswa berkurang, mengantuk dan akhirnya tujuan belajar tidak akan tercapai. Dalam hal ini diperlukan proses pembelajaran yang bervariasi guna mengatasi kebosanan yang akan dihadapi oleh siswa atau peserta didik. Variasi yang dilakukan oleh pendidik dalam melaksanakan proses pembelajaran adalah untuk meningkatkan hasil prestasi mahasiswa. 
Selain variasi dalam proses pembelajaran, fasilitas belajar yang diperoleh peserta pendidik juga dapat mempengaruhi hasil prestasi belajar mereka. Astuti (2013) menghasilkan suatu penelitian yang menyatakan bahwa terdapat pengaruh positif antara fasilitas belajar yang tersedia dilingkungan sekolah dengan prestasi belajar. Hasil penelitian tersebut didukung dengan adanya Undang-undang Republik Indonesia Nomor 20 Tahun 2003 tentang Sistem Pendidikan Nasional pasal 45 ayat 1 yang menjelaskan "Setiap satuan pendidikan formal dan non formal menyediakan sarana dan prasarana yang memenuhi keperluan pendidikan sesuai dengan pertumbuhan dan perkembangan potensi fisik, kecerdasan intelektual, sosial, emosional, dan kejiwaan peserta didik". Sedangkan kita mengetahui, bahwa fasilitas belajar tidak hanya fasilitas yang tersedia dilingkungan sekolah, namun fasilitas belajar yang disediakan di dalam rumah pun turut berperan serta dalam mempengaruhi prestasi belajar. Dengan alasan tersebut, maka pada penelitian ini peneliti akan menguji pengaruh dari metode pembelajaran variasi dan fasilitas belajar terhadap prestasi mahasiswa Manajemen pada mata kuliah akuntansi pengantar dengan motivasi sebagai variabel moderating. Motivasi menjadi variabel moderating karena variabel tersebut mempengaruhi secara tidak langsung dan dapat memperkuat ataupun memperlemah metode pembelajaran yang sudah ditentukan oleh pendidik.

\section{Proses Pendidikan}

Motivasi dapat dijadikan sebagai unsur penyebab terjadinya perbuatan belajar. Motivasi sangat dibutuhkan oleh setiap individu yang dapat timbul dari diri sendiri maupun dari luar sehingga dapat merangsang dalam melakukan suatu tindakan misalnya seperti motivasi belajar. Upaya untuk mencapai keberhasilan dalam proses pembelajaran membutuhkan ketersediaan bahan ajar sebagai acuan dalam pencapaian tujuan belajar secara efisien dan efektif.Proses pendidikan akan berlangsung secara efisien dan efektif jika dalam proses tersebut terjadi suasana belajar yang menyenangkan. Sehingga dapat disimpulkan bahwa dalam pelaksanaan proses pendidikan diperlukan kerja sama antara pendidik dan peserta didik untuk menciptakan suasana yang baik dan menyenangkan dan pada akhirnya akan menentukan timbulnya motivasi dan keberhasilan peserta didik maupun pendidik. Peserta dapat belajar secara efisien dan efektif apabila berbadan sehat, memiliki inteligensi yang memadai, siap untuk melakukan kegiatan belajar, memiliki bakat khusus, dan pengalaman yang bertalian dengan pelajaran, serta memiliki minat untuk belajar. Peserta didik yang sakit/kurang sehat, inteligensi rendah, belum siap belajar, tidak berbakat untuk mempelajari sesuatu, dan tidak memiliki pengalaman yang memadai, kiranya akan mempengaruhi kelancaran kegiatan dan mutu hasil belajarnya.

$$
\text { Wahyudi (2003) menyebutkan }
$$
pembelajaran merupakan proses yang kompleks 
dan dipengaruhi oleh beberapa faktor yang dapat dikelompokkan ke dalam faktor internal dan faktor eksternal. Faktor internal yang mempengaruhi yaitu usia siswa, kemampuan dan motivasi diri, minat, dan bakat sedangkan faktor eksternal antara lain terdiri dari kemampuan guru mengajar, fasilitas belajar, dan lingkungan belajar di sekolah. Sehingga dapat disimpulkan keberhasilan dari proses pembelajaran haruslah ada sinergi diantara faktor-faktor tersebut. Artinya apabila seorang pendidik memiliki kemampuan mengajar yang baik namun tidak didukung dengan fasilitas yang mendukung serta tidak adanya motivasi belajar yang dimiliki oleh peserta didik, maka proses pembelajaran tersebut dapat dipastikan tidak akan tercapai. Sehingga disini pendidik harus menciptakan motivasi belajar kepada peserta didik dan mencari fasilitas yang mendukung dalam proses belajar mengajar dan akhirnya akan terciptanya proses pembelajaran yang efektif dan efisien.

\section{Penggunaan Media Pembelajaran}

Penentuan penggunaan media pembelajaran dalam proses belajar mengajar pada pendidikan formal maupun informal sangatlah penting dalam pencapaian keberhasilan sebuah pendidikan. Namun sebelum membahas lebih jauh tentang media pembelajaran, akan lebih baik bila memahami apa yang dimaksud dengan media, belajar, dan pembelajaran. Media dapat dikatakan sebagai suatu alat yang berfungsi dalam membantu pendidik untuk menyampaikan pesan kepada pada peserta didik. Dengan bantuan media juga akan membantu dalam kelancaran proses belajar mengajar pada pendidikan formal maupun informal. Diharapkan dengan adanya media, proses belajar mengajar akan merangsang perhatian peserta didik, menarik minat dan perhatian peserta didik dan perasaan peserta didik. Dalam kegiatan belajar dibutuhkan suatu pembelajaran sehingga ilmu pengetahuan yang diserap atau dipahami dapat diperoleh dengan maksimal. Pendidik dalam melaksanakan pembelajaran berperan sebagai media penyambung dalam perolehan ilmu dan pengetahuan serta pembentuk karakter dalam bersikap sehingga peserta didik dapat belajar dengan baik dan benar. Seorang pendidik haruslah kreatif dalam menjalankan proses pembelajaran, tujuannya adalah agar para peserta didik tidak mengalami kejenuhan dalam pembelajaran dan akhirnya berdampak pada motivasi belajar.

\section{Motivasi Belajar}

Oemar (2013: 105) menjelaskan bahwa pengajaran tradisional menitikberatkan pada metode imposisi, yaitu pengajaran dengan cara penuangan hal-hal yang dianggap penting oleh guru bagi siswanya. Dan cara ini tidak mempertimbangkan bagaimana kesanggupan, kebutuhan, minat dan tingkat perkembangan serta pemahaman siswa. Penelitian terbaru menemukan bahwa faktor peserta didik dianggap sebagai sesuatu yang menentukan pelaksanaan dan keberhasilan proses pembelajaran. Disinilah peran seorang guru yang 
besar untuk berupaya agar peserta didik mau belajar dan memiliki keinginan belajar terus menerus sehingga memiliki motivasi yang tinggi.

\section{Fasilitas Belajar}

Fasilitas belajar merupakan semua yang berkaitan dengan proses pembelajaran sehingga dapat mempengaruhi prestasi belajar. Fasilitas belajar ini pula yang biasa dikenal dengan sarana dan prasarana yang disediakan ditempat belajar baik di rumah maupun dilingkungan pendidikan. Dan komponen fasilitas belajar yang menjadi unsur penunjang belajar terdapat tiga komponen yang saling berkaitan satu sama lainnya, antara lain media atau alat bantu belajar, peralatanperlengkapan belajar, dan ruangan belajar (Hamalik, 2003).

\section{Prestasi Belajar}

Dalam melaksanakan pembelajaran yang dilakukan oleh pendidik dan peserta didik, prestasi belajar mahasiswa merupakan output dalam penilaian mahasiswa dan pendidik sehingga dapat diketahui keberhasilan dari proses pembelajaran tersebut. Menurut Bakri (1994:21) prestasi belajar adalah penilaian pendidikan tentang perkembangan dan kemajuan murid yang berkenaan dengan penguasaan bahan pelajaran yang disajikan kepada mereka serta nilai-nilai yang terdapat dalam kurikulum. Mediawati (2011) menyimpulkan bahwa pada hakekatnya prestasi belajar harus ditandai dengan adanya perubahan perilaku pada diri siswa setelah selesai mengikuti proses pembelajaran yang berupa adanya perubahan positif mengenai pengetahuan, sikap dan keterampilan psikomotor (skills).

Dalam upaya mengetahui tingkat pencapaian prestasi belajar atau hasil belajar mahasiswa maka diperlukan adanya suatu pengukuran terhadap prestasi belajar atau hasil belajar mahasiswa tersebut. Menurut Strisno Hadi dalam Adiningsih (2012) "Pengukuran dapat diartikan sebagai suatu tindakan untuk mengidentifikasikan besar kecilnya gejala”. Hasil pengukuran yang dapat digunakan adalah berupa angka atau uraian tentang hasil nyata yang menunjukkan derajat kualitas, kuantitas dan eksistensi keadaan yang diukur. Dalam proses pembelajaran cara yang dapat digunakan untuk mengukur suatu prestasi belajar atau hasil belajar yaitu dengan menggunakan tes sebagai alat ukur. Tes hasil prestasi atau hasil belajar yaitu dengan didasarkan pada kompetensi dalam menyelesaikan penyusunan laporan keuangan sesuai dengan siklus akuntansi.

\section{Pengukuran Prestasi Belajar}

Untuk mengetahui seberapa besar tingkat keberhasilan atau prestasi mahasiswa atau hasil belajar yang dicapai, maka perlu diadakan suatu pengukuran terhadap prestasi belajar. Menurut Hadi dalam Adiningsih (2012) pengukuran dapat diartikan sebagai suatu tindakan untuk mengidentifikasikan besar kecilnya gejala. Dimana hasil dari pengukuran tersebut dapat berupa angka atau uraian tentang kenyataan 
yang menggambarkan derajat kualitas, kuantitas dan eksistensi keadaan yang diukur. Cara yang dapat digunakan untuk mengukur prestasi belajar adalah dengan melakukan tes kompetensi dan tes inilah yang dijadikan sebagai alat ukur dalam penilaian suatu keberhasilan peserta didik. Tes kompetensi yang digunakan dalam penelitian ini adalah dengan mengerjakan laporan keuangan sesuai dengan siklus akuntansi yaitu dimulai dengan adanya suatu transaksi yang kemudian dilakukan penjurnalan dan sampai menjadi suatu laporan keuangan yang informatif.

\section{Keberhasilan Pembelajaran}

Untuk mencapai keberhasilan dalam pembelajaran, pendidik perlu melakukan pengujian dalam menilai tingkat keberhasilan tersebut. Fungsi dari penilaian adalah untuk memberikan umpan balik kepada pendidik yang dapat digunakan sebagai perbaikan proses pembelajaran terutama apabila terdapat peserta didik yang belum berhasil. Dalam menilai tingkat keberhasilan, maka pendidik perlu mengetahui apa saja yang menjadi indikator keberhasilan dalam proses pembelajaran. Suci (2008) melakukan penelitian tentang menilai keberhasilan dalam pemahaman mata kuliah dengan melibatkan pembelajaran berbasis masalah dengan pendekatan kooperatif. Hasil dari penelitian tersebut yaitu dengan metode tersebut meningkatkan aktivitas mahasiswa dalam kegiatan belajar mengajar serta meningkatkan hasil belajar mata kuliah teori akuntansi dan mendapatkan respon yang positif dari mahasiswa karena pembelajaran menjadi lebih bermakna. Umpan balik penilaian merupakan metode atau cara guru dalam memberikan respon terhadap siswa baik lisan maupun tulisan. Dengan tulisan misalnya diberikan catatan-catatan yang menyenangkan, membangkitkan semangat, memberi dorongan agar siswa senang belajar (Maonde, 2011: 45).

\section{Kerangka Teoritis yang Dipakai dan Hipotesis}

Akuntansi sangat dibutuhkan pada hampir seluruh perusahaan karena segala kegiatan yang terjadi pada perusahaan disajikan melalui bantuan sistem pencatatan akuntansi. Karena akuntansi memiliki peran yang besar bagi pengguna laporan keuangan maka pendidikan akuntansi harus diajarkan dengan tepat. Ketepatan pengajaran tersebut dapat dilihat dari sisi bagaimana pendidik menyampaikan informasi kepada para peserta didik sehingga dapat dipahami oleh mereka. Penentuan ketepatan pengajaran ditentukan oleh pendidik dalam metode penyampaian materi bahan ajar kepada para mahasiswa. Metode penyampaian materi sangat beragam, namun dalam penelitian ini peneliti hanya menggunakan metode pembelajaran bervariasi. Diharapkan dengan menerapkan metode pembelajaran bervariasi, mahasiswa akan dapat meningkatkan prestasi belajar. Namun apapun penerapan metode pembelajaran yang diterapkan oleh dosen, prestasi belajar tidak akan dicapai secara 
maksimal ketika faktor-faktor lain terganggu, antara lain mahasiswa tidak memiliki motivasi diri untuk meraih keberhasilan dan mereka tidak memiliki fasilitas belajar yang memadai. Sehingga dengan alasan ini maka dapat disimpulkan bahwa prestasi belajar akan dapat dicapai dengan maksimal ketika individu memiliki motivasi diri yang baik dan mendapatkan fasilitas belajar yang memadai. Mengacu pada rumusan masalah dan kerangka pikir penelitian, maka hipotesis dari penelitian ini adalah sebagai berikut:

$\mathrm{H}_{1} \quad$ : Metode pembelajaran bervariasi akan : meningkatkan prestasi belajar :

: mahasiswa.

$\mathrm{H}_{2} \quad$ : Fasilitas yang dipengaruhi motivasi : akan meningkatkan prestasi belajar : mahasiswa.

$\mathrm{H}_{3} \quad$ : Metode pembelajaran bervariasi dan : fasilitas belajar yang dipengaruhi : motivasi akan meningkatkan prestasi : belajar mahasiswa.

\section{Metoda Penelitian}

Penelitian yang dilakukan termasuk dalam pengujian hipotesis karena penelitian ini digunakan untuk membuktikan secara empiris hipotesis-hipotesis yang telah dirumuskan oleh peneliti dengan pengujian hipotesis penelitian korelasional. Waktu yang digunakan dalam penelitian ini adalah tahun ajaran 2014-2015. Prosedur pengumpulan data yang digunakan dalam penelitian ini adalah data langsung yang diperoleh langsung dari hasil tes mahasiswa yang menjadi sampel setelah mendapatkan perlakukan proses pembelajaran dengan metode bervariasi. Kemudian dibagikan kasus tentang pencatatan laporan keuangan sesuai dengan siklus akuntansi untuk dikerjakan. Hasil dari penyelesaian kasus tersebut digunakan sebagai ukuran tingkat keberhasilan mahasiswa Manajemen di mata kuliah Akuntansi Pengantar. Mahasiswa tidak hanya menyelesaikan kasus yang diberikan, namun mereka juga akan mengisi kuesioner yang bertujuan untuk mengetahui seberapa besar motivasi yang mereka miliki terhadap mata kuliah Akuntansi Pengantar serta fasilitas yang mereka miliki di rumah. Selain kuesioner motivasi, mahasiswa juga diberikan kuesioner tentang metode mengajar dosen yang dapat digunakan sebagai bukti bahwa dosen telah menerapkan metode pembelajaran bervariasi.

Secara operasional berdasarkan permasalahan dan hipotesis yang telah dirumuskan, maka variabel-variabel yang akan dianalisis adalah variabel independen atau biasa disebut dengan variabel bebas pada penelitian ini adalah metode pembelajaran bervariasi $\left(X_{1}\right)$, fasilitas belajar $\left(\mathrm{X}_{2}\right)$ dan motivasi $(\mathrm{Z})$. Dimana motivasi sebagai variabel moderating yang mana akan dapat memperkuat ataupun memperlemah metode pembelajaran dan fasilitas belajar dalam menghasilkan prestasi mahasiswa. Variabel dependen atau biasa disebut dengan variabel terikat pada penelitian ini adalah prestasi mahasiswa (Y) yang mana hasilkan dipengaruhi 
oleh variabel model pembelajaran bervariasi yang diperkuat ataupun diperlemah oleh variabel motivasi.

Pada penelitian ini, peneliti menggunakan variabel motivasi sebagai variabel moderating. Dengan kata lain variabel motivasi dapat memperkuat atau memperlemah hubungan antara metode pembelajaran bervariasi dengan prestasi mahasiswa. Pengujian yang dilakukan untuk melihat hubungan dari ketiga variabel tersebut, maka dalam penelitian ini pengujian regresi akan menggunakan uji interaksi. Uji interaksi atau sering disebut dengan Moderated Regression Analysis (MRA) merupakan aplikasi khusus regresi berganda linear dimana dalam persamaan regresinya mengandung unsur interaksi (Ghozali, 2006:200). Untuk itu diformulasikan model MRA sebagai berikut:

$$
\mathrm{Y}=\mathrm{a}+\mathrm{b}_{1} \mathrm{X}_{1}+\mathrm{b}_{2} \mathrm{X}_{2}+\mathrm{b}_{3} \mathrm{Z}+\mathrm{b}_{4} \mathrm{X}_{1} \mathrm{X}_{2} \mathrm{Z}+\mathrm{e}
$$

Dimana:

$\begin{array}{ll}\mathrm{Y} & =\text { Prestasi Mahasiswa } \\ \mathrm{a} & =\text { Konstanta } \\ \mathrm{b}_{1}-\mathrm{b}_{4} & =\text { Koefisien arah regresi } \\ \mathrm{X}_{1} & =\quad \text { Model pembelajaran } \\ \text { bervariasi } & \\ \mathrm{X}_{2} & =\text { Fasilitas belajar } \\ \mathrm{Z} & =\text { Motivasi } \\ \mathrm{e} & =\text { Error }\end{array}$

Untuk menganalisis pengaruh variabelvariabel independen terhadap variabel dependen digunakan metode statistik dengan tingkat taraf signifikansi $\alpha=0,05$ yang artinya derajad kesalahan sebesar 5\%. Pengujian hipotesis dilakukan dengan analisis statistik regresi berganda, yang terdiri Uji F (uji signifikansi simultan) dan Uji t (uji signifikansi parameter individual). Uji $\mathrm{F}$ menunjukkan apakah semua variabel independen atau bebas yang dimasukkan dalam model mempunyai pengaruh secara bersama-sama terhadap variabel dependen atau terikat. Uji $\mathrm{t}$ menunjukkan seberapa jauh pengaruh satu variabel penjelas atau independen secara individual dalam menerangkan variasi variabel dependen (Ghozali, 2007: 84).

\section{ANALISIS DATA DAN PEMBAHASAN}

Berdasarkan hasil pengolahan data, maka persamaan regresi dalam penelitian ini adalah:

$$
\begin{aligned}
& Y=4,226+0,277 X_{1}-0,789 Z+0,261 X_{1} Z \\
& Y=2,467+0,219 X_{2}-0,218 Z+0,401 X_{2} Z
\end{aligned}
$$

Koefisien regresi variabel menunjukkan dua hal:

1. Menunjukkan besarnya perubahan variabel terikat jika tanpa ada pengaruh variabel bebas.

2. Koefisien regresi menunjukkan arah perubahan antara variabel bebas terhadap variabel terikat. Koefisien regresi yang bertanda positif menunjukkan perubahan yang searah antara variabel bebas terhadap variabel terikat, sedangkan koefisien regresi yang bertanda negatif menunjukkan arah perubahan yang berlawanan arah antara variabel bebas terhadap variabel terikat. 
3. Tabel 1. Hasil Perhitungan Regresi Moderator 1

\begin{tabular}{|c|c|c|c|c|}
\hline Variabel & Koefisien Regresi & Standart Error & $\mathbf{t}_{\text {hitung }}$ & Probability \\
\hline $\mathrm{X}_{1}$ & 0,277 & 0,426 & 0,649 & 0,520 \\
\hline $\mathrm{Z}$ & $-0,789$ & 0,449 & $-1,754$ & 0,086 \\
\hline $\mathrm{X}_{1} \mathrm{Z}$ & 0,261 & 0,086 & 3,023 & 0,004 \\
\hline $\begin{array}{l}\text { Constant } \\
\mathrm{R}^{2}\end{array}$ & $\begin{array}{l}= \\
=\end{array}$ & $\begin{array}{l}4,226 \\
0,193\end{array}$ & & \\
\hline $\mathrm{F}_{\text {hitung }}$ & $=$ & 3.594 & & \\
\hline Probability & $=$ & 0,021 & & \\
\hline
\end{tabular}

Dalam perhitungan menunjukkan tidak semua variabel bebas memiliki koefisien bertanda positif, makna dari besaran yang ada adalah:

a. Tanpa metode pembelajaran bervariasi, motivasi belajar, dan moderator sebagai variabel bebas, maka prestasi belajar mahasiswa akan sebesar 4,226.

b. Koefisien metode pembelajaran bervariasi $\left(\mathrm{X}_{1}\right)$ sebesar 0,277 , berarti jika variabel bebas metode pembelajaran dosen meningkat, maka prestasi belajar mahasiswa mengalami peningkatan.

c. Koefisien regresi motivasi belajar (Z) sebesar $-0,789$ berarti jika variabel bebas motivasi belajar meningkat, maka prestasi belajar mahasiswa mengalami penurunan.

d. Koefisien regresi moderator $\left(\mathrm{X}_{1} \mathrm{Z}\right)$ sebesar 0,261 , berarti jika variabel bebas moderator meningkat, maka prestasi belajar mahasiswa mengalami peningkatan.

Tabel 2. Hasil Perhitungan Regresi Moderator 2

\begin{tabular}{|c|c|c|c|c|}
\hline Variabel & Koefisien Regresi & Standart Error & $\mathbf{t}_{\text {hitung }}$ & Probability \\
\hline $\mathrm{X}_{2}$ & 0,219 & 0,262 & 0,834 & 0,409 \\
\hline $\mathrm{Z}$ & $-0,218$ & 0,303 & $-0,719$ & 0,476 \\
\hline $\mathrm{X}_{2} \mathrm{Z}$ & 0,401 & 0,085 & 4,704 & 0,000 \\
\hline Constant & $=$ & 2.467 & & \\
\hline $\mathrm{R}^{2}$ & $=$ & 0,342 & & \\
\hline$F_{\text {hitung }}$ & $=$ & 7,799 & & \\
\hline Probability & $=$ & 0,000 & & \\
\hline
\end{tabular}

Dalam perhitungan menunjukkan tidak semua variabel bebas memiliki koefisien bertanda positif, makna dari besaran yang ada adalah:

a. Tanpa fasilitas belajar, motivasi belajar, dan moderator sebagai variabel bebas, maka prestasi belajar mahasiswa akan sebesar 2,467 . b. Koefisien fasilitas belajar $\left(\mathrm{X}_{2}\right)$ sebesar 0,219 , berarti jika variabel bebas fasilitas belajar meningkat, maka prestasi belajar mahasiswa mengalami peningkatan.

c. Koefisien regresi motivasi belajar (Z) sebesar $-0,218$ berarti jika variabel bebas 
motivasi belajar meningkat, maka prestasi belajar mahasiswa mengalami penurunan.

d. Koefisien regresi moderator $\left(\mathrm{X}_{2} \mathrm{Z}\right)$ sebesar 0,401, berarti jika variabel bebas moderator meningkat, maka prestasi belajar mahasiswa mengalami peningkatan.

\section{Pengujian Hipotesis}

Pada tingkat signifikansi 0,05 dan derajat kebebasan sebesar 3 dan $45(\mathrm{df}=3$ dan 45), maka diperoleh $F_{\text {Tabel }}$ sebesar 2,81. Nilai $F_{\text {hitung }}$ berdasarkan perhitungan dengan menggunakan alat bantu statistik, yang diolah melalui program komputer sebesar 3,594 dengan demikian nilai $\mathrm{F}_{\text {hitung }}$ lebih besar dibandingkan $\mathrm{F}_{\text {Tabel }}\left(\mathrm{F}_{\text {hitung }}=\right.$ 3,594 $\left.>\mathrm{F}_{\text {Tabel }}=2,81\right)$ dan tingkat signifikansi sebesar 0,021 < dari level of signifikan yang digunakan yaitu 0,05. Dapat disimpulkan bahwa secara simultan variabel pembelajaran dosen, motivasi belajar, dan moderator berpengaruh signifikan terhadap prestasi belajar mahasiswa. Nilai dari koefisien determinasi dari hasil perhitungan sebesar 0,193. Hal ini berarti 19,3\% perubahan variabel terikat (prestasi belajar mahasiswa) mampu dijelaskan oleh variabelvariabel bebas yang dimasukkan dalam model, sedangkan sisanya $80,7 \%$ dijelaskan oleh variabel lain yang tidak dimasukkan dalam model (faktor galat).

Pada tingkat signifikansi 0,05 dan derajat kebebasan sebesar 3 dan 45 ( $\mathrm{df}=3$ dan
45), maka diperoleh $F_{\text {Tabel }}$ sebesar 2,81. Nilai $F$ hitung berdasarkan perhitungan dengan menggunakan alat bantu statistik, yang diolah melalui program komputer sebesar 7,799 dengan demikian nilai $\mathrm{F}_{\text {hitung }}$ lebih besar dibandingkan $\mathrm{F}_{\text {Tabel }}\left(\mathrm{F}_{\text {hitung }}=7,799>\mathrm{F}_{\text {Tabel }}=2,81\right)$ dan tingkat signifikansi sebesar $0,000<$ dari level of signifikan yang digunakan yaitu 0,05. Dapat disimpulkan bahwa secara simultan variabel fasilitas belajar, motivasi belajar, dan moderator berpengaruh signifikan terhadap prestasi belajar mahasiswa. Nilai dari koefisien determinasi dari hasil perhitungan sebesar 0,342 . Hal ini berarti $34,2 \%$ perubahan variabel terikat (prestasi belajar mahasiswa) mampu dijelaskan oleh variabel-variabel bebas yang dimasukkan dalam model, sedangkan sisanya $65,8 \%$ dijelaskan oleh variabel lain yang tidak dimasukkan dalam model (faktor galat).

Uji statistik $\mathrm{t}$ digunakan untuk mengetahui apakah variabel bebas yang dimasukan dalam model secara parsial berpengaruh signifikan terhadap variabel terikat. Metode yang digunakan adalah dengan membandingkan nilai $t_{\text {hitung }}$ dengan $t_{\text {Tabel }}$. Nilai $t_{\text {Tabel }}$ didapat dengan memperhatikan jumlah observasi atau pengamatan $(n=49)$ dan derajat kebebasan (n-k-1), sehingga derajat kebebasan didapat $(49-3-1)=(\mathrm{df}=45)$ dan menggunakan level of significant $(\alpha=0,05)$ serta dengan uji dua arah sehingga diperoleh $\mathrm{t}_{\text {Tabel }}$ sebesar 2,000. 
Tabel 3. Hasil Pengujian Secara Parsial

\begin{tabular}{lccccc}
\hline \multicolumn{1}{c}{ Variabel Bebas } & $\mathbf{t}_{\text {hitung }}$ & $>/<$ & $\mathbf{t}_{\text {Tabel }}$ & Sign & Kesimpulan \\
\hline & \multicolumn{2}{c}{ Moderator $\mathbf{1}$} & & & \\
Metode Mengajar Dosen $\left(\mathrm{X}_{1}\right)$ & 0,649 & $<$ & 2,000 & 0,520 & Tdk Signifikan \\
Motivasi Belajar $(\mathrm{Z})$ & $-1,754$ & $>$ & $-2,000$ & 0,086 & Tdk Signifikan \\
Moderator $\left(\mathrm{X}_{1} \mathrm{Z}\right)$ & 3,023 & $>$ & 2,000 & 0,004 & Signifikan \\
& \multicolumn{2}{c}{ Moderator 2 } & & & \\
Fasilitas Belajar $\left(\mathrm{X}_{2}\right)$ & 0,834 & $<$ & 2,000 & 0,409 & Tdk Signifikan \\
Motivasi Belajar $(\mathrm{Z})$ & $-0,719$ & $>$ & $-2,000$ & 0,476 & Tdk Signifikan \\
$\quad$ Moderator $\left(\mathrm{X}_{2} \mathrm{Z}\right)$ & 4,704 & $>$ & 2,000 & 0,000 & Signifikan \\
\hline
\end{tabular}

Dari pengujian yang terlihat pada tabel tersebut menunjukkan bahwa variabel moderator yang pertama memiliki pengaruh signifikan terhadap prestasi belajar mahasiswa. Sedangkan masingmasing metode mengajar dan motivasi tidak memiliki pengaruh yang signifikan terhadap prestasi belajar. Untuk pengujian moderator yang kedua menunjukkan memiliki pengaruhi yang signifikan terhadap prestasi, namun untuk masing-masing variabel tidak memiliki pengaruhi yang signifikan terhadap prestasi belajar.

\section{Kesimpulan, Implikasi dan Keterbatasan}

Kesimpulan yang dapat ditarik dari hasil pengujian yang sudah dilakukan menunjukkan bahwa variabel metode mengajar bervariasi dan fasilitas memiliki pengaruh yang tidak signifikan, yang artinya terdapat variabelvariabel independen lain yang dapat mempengaruhi variabel dependen secara signifikan. Namun apabila masing-masing variabel independen tersebut di moderasi dengan variabel motivasi belajar, maka metode mengajar dosen dan fasilitas dengan variabel motivasi akan memiliki pengaruh signifikan terhadap prestasi belajar mahasiswa. Artinya dengan adanya metode mengajar bervariasi yang baik dan fasilitas yang tercukupi, dan didukung dengan motivasi belajar dari setiap mahasiswa, maka variabel-variabel tersebut akan menciptakan prestasi belajar mahasiswa yang baik.

Keterbatasan dalam penelitian ini adalah setiap mahasiswa dengan jurusan yang berbeda memiliki tingkat kemampuan intelektual yang berbeda. Hal ini dipengaruhi oleh minat studi masing-masing yang artinya bahwa ketika dilakukan penelitian di jurusan yang lain akan diperoleh hasil yang berbeda. Instansi pendidikan juga dapat mempengaruhi hasil penelitian, selain itu kualitas dan kompetensi dari pendidik akan mempengaruhi hasil prestasi belajar pula. Dalam penelitian selanjutnya diharapkan peneliti dapat mengidentifikasi lebih jauh lagi variabel-variabel yang dapat mempengaruhi prestasi belajar mahasiswa secara umum. Dengan adanya hasil penelitian yang telah dilakukan diharapkan kepada para pendidik untuk lebih kreatif dalam mengelola kelas untuk dapat memahami karakter dan kemampuan 
mahasiswa sehingga seluruh mahasiswa dapat menerima proses pendidikan dengan baik dan akhirnya akan menghasilkan lulusan yang kompeten.

\section{DAFTAR PUSTAKA}

Adiningsih, D. (2012). Pengaruh Persepsi Siswa Tentang Metode Mengajar Guru Dan Kemandirian Belajar Terhadap Prestasi Belajar Akuntansi Siswa Kelas X Program Keahlian Akuntansi SMK Batik Perbaik Purworejo Tahun Ajaran 2011/2012. Kajian Pendidikan Akuntansi Indonesia, 1(2)

Bates, H. L., \& Waldrup, B. E. (2006). The effect of teaching technology on the performance and attitudes of accounting principles students. Academy of Educational Leadership Journal, 10(3), 79.

Djamarah, S. B., \& Zain, A. (2006). Strategi belajar mengajar.

Giantera, D. R. (2013). Pengaruh Fasilitas Belajar dan Motivasi Belajar Terhadap Hasil Belajar Siswa Mata Pelajaran Peralatan Kantor Pada Siswa Kelas X Program Keahlian Administrasi Perkantoran SMK Cokroaminoto 1 Banjarnegara (Doctoral dissertation, Universitas Negeri Semarang).

Ghozali, I. (2006). Aplikasi analisis multivariate dengan program SPSS.
Badan

Penerbit

Universitas

Diponegoro.

Hamalik, O. (2004). Proses belajar mengajar. Bumi Aksara.

Inayah, R. (2013). Pengaruh kompetensi guru, motivasi belajar siswa, dan fasilitas belajar terhadap prestasi belajar mata pelajaran ekonomi pada siswa kelas XI IPS SMA Negeri 1 Lasem Jawa Tengah Tahun Pelajaran 2011/2012. Jurnal pendidikan insan mandiri, 2(1).

BPFE, U. (2007). Metodologi Penelitian Bisnis: Salah Kaprah Dan PengalamanPengalaman. View in (Google Scholar).

Jusup, A. H. (2011). Dasar-dasar Akuntansi. Jilid 1. Edisi 7. Yogyakarta: Bagian Penerbitan Sekolah Tinggi Ilmu Ekonomi $Y K P N$

Maonde, F. (2011). Aplikasi Penelitian Eksperimen Dalam Bidang Pendidikan dan Sosial. Kendari: Unit Penerbitan dan Percetakan Universitas Haluoleo.

Mediawati, E. (2011). Pembelajaran akuntansi keuangan melalui media komik untuk meningkatkan prestasi mahasiswa. Jurnal penelitian pendidikan, 12(1), 68-76.

Sanaky, H. A. (2011). Media Pembelajaran Buku Pegangan Wajib Guru dan Dosen. Yogyakarta: Kaukaba Dipantara. 
Sekaran, U., \& Bougie, R. (2006). Research method for business. Salemba Empat, Jakarta.

Suci, N. M. (2008). Penerapan Model Problem Based Learning untuk meningkatkan partisipasi belajar dan hasil belajar teori akuntansi mahasiswa jurusan ekonomi Undiksha. Jurnal Penelitian dan Pengembangan Pendidikan, 2(1), 74-86.

Sugiyono. (2004). Metode Penelitian Bisnis.

Bandung: Penerbit CV Alfabeta

Sukmadinata, N. S. (2013). Metode Penelitian Pendidikan. Bandung: PT Remaja Rosdakarya

Wahyudi. (2003). Penyusunan dan Validasi Kuesioner Iklim Lingkungan Pembelajaran di Kelas. Jurnal Pendidikan dan Kebudayaan 